\title{
Una nota a la correspondencia de Valera: la fuente griega de una estrofa alemana citada por don Juan
}

\author{
JAIME SILES \\ Instịtuto Español, Viena
}

A José Luis Melena

El 16 de enero de 1893, don Juan Valera, que acababa de sufrir un desaire urdido contra él por altos dignatarios de la diplomacia vaticana ${ }^{1}$, era nombrado embajador en Viena. El 27 de febrero tomaba posesión, y el 21 de marzo presentaba sus credenciales ante S. M. Imperial. Unos meses después, el 29 de julio, escribe al dramaturgo Tamayo y Baus, refiriéndole, con todo lujo de detalles, los pormenores de la vida vienesa en sus vertientes frívola y social ${ }^{2}$. Y, entre otras amenida-

1 Sobre los pormenores de este revés, motivado en parte por la prensa neocatólica, puede verse la carta a don Victoriano Agüeros, publicada por Carmen BravoVillasante en su Vida de Juan Valera, Madrid, 1974, pp. 268-271.

2 Ambas vertientes, muy bien representadas en la correspondencia de Valera, han sido objeto de un divertido comentario de José Luis Cano, «Valera íntimo», recogido en su libro Españoles de dos siglos (de Valera a nuestros días), Madrid, 1974, pp. 37-43. Lo frívolo aludido aquí es la siguiente información, tan del gusto de 
des de carácter culto y galante, le comenta a don Manuel esta curiosidad: una comida, en la quinta de la viuda del librero Gerold, a la que asistieron, como invitados, «el Director de la Biblioteca Imperial, el escultor Zumbusch, autor del hermoso monumento de la Emperatriz María Teresa, $y$ otros literatos y artistas» ${ }^{3}$, amén del propio Valera y una sobrina de la anfitriona «muy guapa, alegre, alta, ágil, y que trinca, baila, tira a la pistola, juega al billar y fuma cigarrillos con mucha gracia» ${ }^{4}$. "A los postres - continúa Valera-todos, con vasos en las manos, o de Champagne o de Chipre o de Malvasía, que se chocaban y eran el acompañamiento, se cantó a la redonda una preciosa canción báquica, música de Haydn. Es una estrofa sola -especifica-y en el que termina se bebe a su salud y vuelta a empezar, hasta que se bebe a la salud de todos. Me dijeron que las palabras de la canción son de una poetisa griega, llamada Praxila (sic)». Valera, que había aprendido el griego de una manera muy particular ${ }^{5}$, y que era un erudito o, cuando menos, un hombre de letras con intereses de erudito, como transparenta su correspondencia aquí y allá ${ }^{6}$, notifica sus dudas al respecto: «Como no tengo aquí el "Corpus poetarum graecorum" - se lamenta- no he podido cerciorarme» ${ }^{7}$. Luego, transcribe el texto en alemán:

Lebe, liebe, trinke und schwärme

Und bekräntze dich mit mir:

Härme dich, wenn ich mich härme

Und sei wieder froh mit mir.

Valera: «S6lo de [prostitutas] con cartilla y regimentadas hay 30.000 en Viena, muy guapas en su mayoría. [Prostitutas] de afición (guárdeme $V$. el secreto) debe de haber lo menos 200.000; pero todas candorosamente.»Y Y guarda relación con su informe enviado al marqués de la Vega de Armijo, al que comunica el 28 de marzo de 1893, esta intimidad del emperador: «Lo más extraño que dicen es que S. M. Imperial y Real Apostólica hizo, años ha, un cruel regalo a su Augusta consorte, infundiéndole el morbo cantado por Fracastoro y que

in Latio per tristia bella

Gallorum irrupit, nomenque a gente recepit.

Convencida ella entonces harto dolorosamente de la infidelidad conyugal, no consiente más en ir al tálamo; pero él se consuela con otras mujeres». Lo social, en fin, es la muy puntual y precisa descripción que hace de las nacionalidades y lenguas del país.

3 Cf. para el texto citado, como para los transcritos en la nota 2, Correspondencia de don Juan Valera (1895-1905). Cartas inéditas publicadas con una introducción de Cyrus C. DeCoster, Valencia, 1956, p. 199.

4 Ibídem.

5 Cf. A. Gallego Morell, «Notas a Valera», recogido en En torno a Garcilaso y otros ensayos, Madrid, 1970, pp. 65-66.

6 Cf., además del epistolario editado por DeCoster y citado supra en nota 3, el libro Juan Valera: Cartas íntimas (1853-1897). Nota preliminar, estudio, edición y notas de Carlos Sáenz de Tejada Benvenuti, Madrid, 1974.

7 Ibidem. 
Y lo traduce: «Vive, ama, bebe y sueña y corónate conmigo: entristécete cuando yo me entristezco y alégrate conmigo de nuevo» ${ }^{8}$.

A lo que se me alcanza, y por lo que he podido consultar, la estrofa en cuestión no es de Praxilla, sino que procede, más bien, de uno de los carmina convivialia griegos, al que corresponde casi (o sin casi) tal cual. La confusión con Praxilla puede explicarse por la intertextualidad que algunos de los fragmentos de ésta tienen con los carmina convivialia: sobre todo, el fr. 3 con el Carm. Conv. 14, y el fr. 4, con el Carm. Conv. 20. Dada su similitud (o la proximidad textual en alguna edición), el interlocutor de Valera bien pudo confundirlos. En cualquier caso, he aquí el texto griego ${ }^{9}$, del que la estrofa alemana, transmitida por Valera, parece ser exacta traducción:

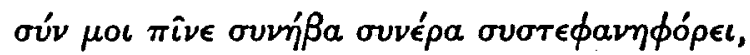

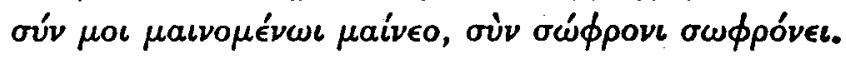

8 Correspondencia..., p. 200.

9 Cf. Poetae Melici Graeci, ed. de D. L. Page, Oxford, 1967, p. 477, n. ${ }^{\circ} 902$. 